7. Reprod. Fert. (1975) 45, 533-535

\title{
HETEROSPERMIC INSEMINATION AND ITS EFFECT ON THE OFFSPRING RATIO IN RATS
}

\author{
O. P. SHARMA* AND R. L. HAYS \\ Department of Dairy Science, University of Illinois, Urbana, \\ Illinois 60801, U.S.A.
}

(Received 28th April 1975)

The consecutive insemination of an oestrous female by two different males has often been reported to yield disproportionate numbers of offspring. This disparity in the number of offspring has been suggested as being independent of the number of spermatozoa from each sire (Allen \& Champion, 1955; Edwards, 1965; Roche et al., 1968; O'Reilly et al., 1972). The heterospermic impregnation technique has also been used to determine the effect of semen storage and semen diluents and to evaluate the relative fertility of males (Roche et al., 1968; Beatty et al., 1969). In the mouse (Lewis \& Wright, 1935) and rat (Blandau \& Money, 1944) sperm transport is almost instantaneous and it might be expected that the spermatozoa deposited by the first sire would be at an advantage in reaching the site of fertilization before the spermatozoa of the second sire. The present study was undertaken to determine the effect of heterospermic impregnation in rats on the proportion of offspring and the time advantage of one male over the other in relation to time of semen deposition and ovulation.

Eighty-four sexually mature albino female rats (Holtzman strain), weighing 110-130 g, were used for breeding with six mature fertile Norwegian hooded $(\mathrm{H})$ and six albino $(\mathrm{A})$ male rats. Identification of the offspring was simple since the hooded are dominant. The rats were housed in a room at constant temperature $\left(75 \pm 2^{\circ} \mathrm{F}\right)$, fed a commercial laboratory ration and given an ample supply of water. The photoperiod was regulated as $14 \mathrm{hr}$ light: $10 \mathrm{hr}$ dark.

In Exp. 1, each sexually receptive female was placed with an $\mathbf{H}$ or A male. After the male had ejaculated the female was removed and kept in a separate cage for 5-7 min (rest period). Insemination was confirmed by the presence of a vaginal plug.

During the rest period the plug was removed by forceps and the female was then put with a male of the other strain until ejaculation occurred. The female was then removed and housed separately. The vaginal plug was left in situ. Ten days before the expected day of littering, the female was housed in a littering cage with soft bedding to avoid any loss of young. Fifteen females were mated first by an $\mathrm{H}$ and then an A male (Group 1) and thirteen received an A male first followed by an $\mathrm{H}$ male.

In order to eliminate the effects of individual dominance of one male over the others, 36 female rats were inseminated in Exp. 2 as follows. Females 1 to 6

\footnotetext{
* Present address: Department of Veterinary Science, University of Kentucky, Lexington, Kentucky
} 40506, U.S.A. 
Table 1. The numbers and types of offspring from albino female rats mated by hooded and albino males (Exp. 2)

\begin{tabular}{|c|c|c|c|c|c|c|c|c|}
\hline \multirow{2}{*}{ Hooded sire } & \multirow{2}{*}{ Offspring } & \multicolumn{6}{|c|}{ Albino sire } & \multirow{2}{*}{ Total } \\
\hline & & $A 1$ & $A 2$ & $A 3$ & $A 4$ & $A 5$ & $A 6$ & \\
\hline $\mathrm{H} 1$ & $\begin{array}{l}\mathrm{H} \\
\mathrm{A}\end{array}$ & $\begin{array}{l}4 \\
6\end{array}$ & $\begin{array}{l}0 \\
6\end{array}$ & $\begin{array}{l}1 \\
4\end{array}$ & $\begin{array}{l}5 \\
5\end{array}$ & $\begin{array}{l}1 \\
3\end{array}$ & $\begin{array}{l}4 \\
2\end{array}$ & $\begin{array}{l}15 \\
26\end{array}$ \\
\hline $\mathrm{H} 2$ & $\begin{array}{l}\mathbf{H} \\
\text { A }\end{array}$ & $\begin{array}{l}3 \\
7\end{array}$ & $\begin{array}{l}1 \\
7\end{array}$ & $\begin{array}{l}3 \\
6\end{array}$ & $\begin{array}{l}4 \\
6\end{array}$ & $\begin{array}{l}3 \\
3\end{array}$ & $\begin{array}{l}3 \\
8\end{array}$ & $\begin{array}{l}17 \\
37\end{array}$ \\
\hline $\mathrm{H} 3$ & $\begin{array}{l}\mathrm{H} \\
\mathrm{A}\end{array}$ & $\begin{array}{r}13 \\
0\end{array}$ & $\begin{array}{r}0 \\
10\end{array}$ & $\begin{array}{l}4 \\
0\end{array}$ & $\begin{array}{l}5 \\
2\end{array}$ & $\begin{array}{l}6 \\
3\end{array}$ & $\begin{array}{l}5 \\
3\end{array}$ & $\begin{array}{l}33 \\
18\end{array}$ \\
\hline $\mathrm{H} 4$ & $\begin{array}{l}\mathrm{H} \\
\mathrm{A}\end{array}$ & $\begin{array}{r}2 \\
11\end{array}$ & $\begin{array}{l}3 \\
6\end{array}$ & $\begin{array}{l}9 \\
2\end{array}$ & $\begin{array}{l}3 \\
6\end{array}$ & $\begin{array}{l}2 \\
9\end{array}$ & $\begin{array}{l}1 \\
9\end{array}$ & $\begin{array}{l}20 \\
43\end{array}$ \\
\hline H5 & $\begin{array}{l}\mathbf{H} \\
\mathrm{A}\end{array}$ & $\begin{array}{r}14 \\
1\end{array}$ & $\begin{array}{l}3 \\
7\end{array}$ & $\begin{array}{r}12 \\
0\end{array}$ & $\begin{array}{l}0 \\
9\end{array}$ & $\begin{array}{l}4 \\
4\end{array}$ & $\begin{array}{r}1 \\
13\end{array}$ & $\begin{array}{l}34 \\
34\end{array}$ \\
\hline H6 & $\begin{array}{l}\mathrm{H} \\
\mathrm{A}\end{array}$ & $\begin{array}{l}4 \\
3\end{array}$ & $\begin{array}{l}4 \\
6\end{array}$ & $\begin{array}{l}8 \\
2\end{array}$ & $\begin{array}{l}0 \\
9\end{array}$ & $\begin{array}{l}1 \\
5\end{array}$ & $\begin{array}{l}1 \\
2\end{array}$ & $\begin{array}{l}19 \\
27\end{array}$ \\
\hline Total & $\begin{array}{l}\mathrm{H} \\
\mathrm{A}\end{array}$ & $\begin{array}{l}40 \\
28\end{array}$ & $\begin{array}{l}11 \\
42\end{array}$ & $\begin{array}{l}37 \\
14\end{array}$ & $\begin{array}{l}17 \\
37\end{array}$ & $\begin{array}{l}17 \\
27\end{array}$ & $\begin{array}{l}16 \\
37\end{array}$ & $\begin{array}{l}138^{*} \\
185^{*}\end{array}$ \\
\hline
\end{tabular}

* Significantly different, $P<0.05$ (Student's $t$ test, Steel \& Torrie, 1960).

were mated by $\mathrm{H}$ male and then Female 1 received Male Al, Female 2 Male $\mathrm{A} 2$, and so on, with Female 6 receiving Male A6. Male $\mathrm{H} 2$ was used for the next six females and then the $\mathrm{Al}$ to $\mathrm{A} 6$ males in sequence leading to Female 36 being inseminated by $\mathrm{H} 6$ and $\mathrm{A} 6$ males.

The results for the females in Exp. 1, Group 1 and Exp. 2 were combined since the order of impregnation by the $\mathrm{H}$ and then the A male was the same. A total of 493 young (average $9 \cdot 6 /$ litter) were obtained from 51 females; 276 young were albino and 217 hooded. The sex ratio was $53 \%$ females.

From the thirteen females in Exp. 1, Group 2, a total of 136 young (average $10.46 /$ litter) was obtained; 61 were albino and 75 hooded, and the sex ratio was $45 \%$ females. The results of Experiment 2 are presented in Table 1 and show that Males A1 and A3 and A5 and A6 have complete dominance over Males $\mathrm{H} 2$ and $\mathrm{H} 4$, respectively, but Males $\mathrm{H} 1$ and $\mathrm{H} 3$ have complete dominance over Males A3, A3 and A6, respectively. Of 323 young born (8.9 young/litter), 185 were albino and 138 hooded. These differences are significant $(P<0 \cdot 05, t$ test, Steel \& Torrie, 1960).

To determine whether the spermatozoa deposited by the first male in one ejaculate are sufficient to provide a normal litter size, and whether the removal of the vaginal plug has any overt effect on the number of young born, twenty mature females were mated with four males only once (Exp. 3); in ten the plug was removed and in the other ten it was left intact. All the females that were inseminated once only conceived and gave birth to a normal litter $(10.3$ young/ litter) at term. The sex ratio was 54.6 males: 45.4 females. No deleterious effect of the removal of the vaginal plug on the number of young born, 55 males and 47 females to females with the plug intact and 56 males and 45 females to females from which the plug had been removed, was observed. 
Spermatozoa that reach the site of fertilization within 5 min of ejaculation can fertilize (Sharma et al., 1968), but when two inseminations occur the spermatozoa are competing with others of their own type and those of the other strain (Roche et al., 1968) as shown by the mixed litters produced by albino females mated by albino and hooded males. The disparity in proportions of offspring derived from such matings cannot be attributed to the variation in the number of spermatozoa deposited by each male, since Martin et al. (1974) found no significant difference in the number of offspring in hens when different proportions of semen from two different males were used in an insemination study. Contrary results on the constancy of proportions of cattle offspring, however, have been reported by Beatty et al. (1969).

The results of the present study show a significant difference $(P<0.05)$ between the proportion of albino and hooded offspring in a heterospermic breeding in favour of the spermatozoa from albino males.

The findings of Adler \& Zolott (1970) that post-coital genital stimulation is contraceptive in rats could not be confirmed in the present study. In Exps 1 and 2 , the genitalia of the female was stimulated by removal of the vaginal plug and by the intromissions and ejaculation of the second male and the results are in agreement with those of Dziuk (1970) that vaginal stimulation does not affect conception. The present study also confirms that spermatozoa from certain males are more likely to fertilize eggs than spermatozoa from other males when used in direct competition or given an advantage in time or in order.

This work was supported by the University of Illinois Agricultural Experiment Station.

\section{REFERENCES}

ADLER, N.T. \& ZoLotT, S.R. (1970) Copulatory behaviour can inhibit pregnancy in female rats. Science, N.Y. 168, 1480-1482.

Alize, C.J. \& Champion, L.R. (1955) Competitive fertilization in the fowl. Poult. Sci. 34, 1332-1342.

Beatty, R.A., Bennett, G.H., Hall, J.G., Hancock, J.L. \& Stewart, D.L. (1969) An experiment with heterospermic insemination in cattle. F. Reprod. Fert. 19, 491-502.

BlandaU, R.J. \& MONEY, W.L. (1944) Observations on rate of transport of spermatozoa in the female genital tract of the rat. Anat. Rec. 90, 255-260.

Dzruk, P.J. (1970) Copulation and inhibition of pregnancy in rats. Science, N.Y. 171, 311.

EDWARDs, R.G. (1965) Selective fertilization following the use of sperm mixtures in the mouse. Nature, Lond. 175, 215-216.

Lewis, W.H. \& WRIGHT, E.S. (1935) On the early development of mouse egg. Contrib. Embryol. 25, $113-146$.

Martin, P.A., Reimers, T.J., Lodge, J.R. \& Dziuk, P.J. (1974) The effect of ratios and numbers of spermatozoa mixed from two males on proportions of offspring. F. Reprod. Fert. 39, 251-258.

O'Reiltx, P.J., Graves, C.N. \& DziuK, P.J. (1972) Heterospermic insemination as a means of evaluating techniques of semen handling. F. Reprod. Fert. 29, 49-56.

Roche, J.F., Dziuk, P.J. \& Lodge, J.R. (1968) Competition between fresh and aged spermatozoa in fertilizing rabbit eggs. F. Reprod. Fert. 16, 155-157.

Sharma, O.P., LODGE, J.R. \& HAYs, R.L. (1968) Fertilization after ligating the oviduct within minutes following mating. $\mathcal{F}$. Reprod. Fert. 18, 179-180.

Steks, R.G.D. \& Torrie, J.H. (1960) Principles and Procedures of Statistics. McGraw-Hill, New York. 